\title{
Developmental approaches to depression
}

\author{
DANTE CICCHETTI, ${ }^{a}$ BARRY NURCOMBE, ${ }^{b}$ AND JUDY GARBER ${ }^{c}$ \\ ${ }^{a}$ Mt. Hope Family Center, Department of Psychology, University of Rochester; \\ Departments of ${ }^{b}$ Psychiatry and ${ }^{C}$ Psychology, Vanderbilt University
}

This special issue of Development and Psychopathology is devoted to developmental approaches to the study of depression. Because the developmental perspective has only recently begun to be applied to the study of the mood disorders, it is hardly surprising that relatively little work exists that focuses on the relation between developmental processes and the affective disorders.

Early attempts to view depression from a developmental perspective primarily involved targeting a particular psychological or psychobiological mechanism known to occur in adult depression in order to discern the possible operation of this process throughout the course of ontogenesis (Cicchetti \& Schneider-Rosen, 1986; Rutter, 1986). Even within the limits of these earlier efforts to consider the implications of the developmental perspective for elucidating the understanding of the affective disorders, it became apparent that there were many domains of development that needed to be taken into account (most notably, socioemotional, cognitive, linguistic, social-cognitive, neurobiological, and neurochemical; see Cicchetti \& Schneider-Rosen, 1986; Puig-Antich, 1986; Radke-Yarrow \& Zahn-Waxler, 1990; Zahn-Waxler \& Kochanska, 1990).

Moreover, from the integrative perspective of developmental psychopathology, it is argued that it is essential to engage in a comprehensive evaluation of those factors (e.g., biological, psychological, environmental, social, intrafamilial; cf. Cicchetti \& Aber, 1986) that may influence the na- ture of individual differences, the continuity of adaptive or maladaptive behavioral patterns, and the different pathways by which the same developmental outcomes may be achieved (Cicchetti \& SchneiderRosen, 1986; Kovacs, 1986; Rutter, 1986; Sroufe \& Rutter, 1984). In practice, this entails a comprehension of and appreciation for the developmental transformations and reorganizations that occur over time; an analysis of the risk and protective factors and mechanisms operating in the child and his or her environment; the investigation of how emergent functions, competencies, and developmental tasks modify the expression of a disorder or lead to new symptoms and difficulties; and the recognition that a particular stress or underlying mechanism may result in different behavioral difficulties, at different times in the developmental process and in different contexts (Cicchetti \& Aber, 1986; Cicchetti \& Schneider-Rosen, 1984; Garber, 1984; Garber \& Dodge, 1991; Kovacs, Feinberg, Crouse-Novak, Paulauskas, \& Finkelstein, 1984; Kovacs, Feinberg, Crouse-Novak, Paulauskas, Pollack, \& Finkelstein, 1984; Nurcombe, in press; Rutter, 1986).

Influenced by the publication of the seminal empirical work of Kovacs and her colleagues (1984), the theoretical writings of Rutter and Garmezy (1983), and the volume integrating developmental and clinical approaches to depression edited by Rutter, Izard, and Read (1986), the past decade has witnessed a proliferation of interest in developmental approaches to the epidemiol- 
ogy, symptomatology, psychobiology, etiology, precursors, onset, course, sequelae, and treatment of depression across the lifespan (see, e.g., Beardslee \& Podorefsky, 1988; Cicchetti \& Schneider-Rosen, 1984, 1986; Davidson, 1991; Downey \& Coyne, 1990; Field, 1989; Harris, Brown, \& Bifulco, 1990; Radke-Yarrow \& Zahn-Waxler, 1990; Rose \& Abramson, in press; Rutter, 1988; Rutter et al., 1986; Trad, 1987; Tronick \& Field, 1986). Continuing in this

\section{References}

Beardslee, W. R., \& Podorefsky, M. (1988). Resilient adolescents whose parents have serious affective and other psychiatric disorders: Importance of self-understanding and relationships. American Journal of Psychiatry, 145, 63-69.

Cicchetti, D., \& Aber, J. L. (1986). Early precursors to later depression: An organizational perspective. In L. Lipsitt \& C. Rovee-Collier (Eds.), Advances in infancy (Vol. 4, pp. 87-137). Norwood, NJ: Ablex.

Cicchetti, D., \& Schneider-Rosen, K. (Eds.). (1984). Childhood depression: A developmental perspective. San Francisco: Jossey-Bass.

Cicchetti, D., \& Schneider-Rosen, K. (1986). An organizational approach to childhood depression. In M. Rutter, C. Izard, \& P. Read (Eds.), Depression in young people: Clinical and developmental perspectives (pp. 71-134). New York: Guilford.

Davidson, R. J. (1991). Cerebral asymmetry and affective disorders: A developmental perspective. In D. Cicchetti \& S. L. Toth (Eds.), Internalizing and externalizing expressions of dysfunction: Rochester Symposium on Developmental Psychopathology (Vol. 2, pp. 123-154). Hillsdale, NJ: Lawrence Erlbaum.

Downey, G., \& Coyne, J. (1990). Children of depressed parents. An integrative review. Psychological Bulletin, 108, 50-76.

Field, T. (1989). Maternal depression effects on infant interaction and attachment behavior. In D. Cicchetti (Ed.), The emergence of a discipline: Rochester Symposium on Developmental Psychopathology (Vol. 1, pp. 139-164). Hillsdale, NJ: Lawrence Erlbaum.

Garber, J. (1984). The developmental progression of depression in female children. In D. Cicchetti \& K. Schneider-Rosen (Eds.), Childhood depression: New directions for child development (pp. 29-58). San Francisco: Jossey-Bass.

Garber, J., \& Dodge, K. (Eds.). (1991). The development of emotion regulation and dysregulation. New York: Cambridge University Press.

Harris, T., Brown, G. W., \& Bifulco, A. (1990). Loss of parent in childhood and adult psychiatric disorder: A tentative overall model. Development and Psychopathology, 2, 311-328.

Kovacs, M. (1986). A developmental perspective on methods and measures in the assessment of de- tradition, the contributors of this special issue address a variety of developmental aspects of depression. We think you will concur that the theoretical, review, and empirical papers that appear in this issue not only reflect recent advances that have occurred in this area but also that they serve as a necessary research agenda if progress in understanding the mechanisms, processes, and developmental course of depression is to continue.

pressive disorders: The clinical interview. In $\mathbf{M}$. Rutter, C. E. Izard, \& P. B. Read (Eds.), Depression in young people: Clinical and developmental perspectives (pp. 435-468). New York: Guilford.

Kovacs, M., Feinberg, T. L., Crouse-Novak, M. A., Paulauskas, S. L., \& Finkelstein, R. (1984). Depressive disorders in childhood. I. A longitudinal prospective study of characteristics and recovery. Archives of General Psychiatry, 41, 229-237.

Kovacs, M., Feinberg, T. L., Crouse-Novak, M. A., Paulauskas, S. L., Pollack, M., \& Finkelstein, R. (1984). Depressive disorders in childhood. II. A longitudinal study of the risk for a subsequent major depression. Archives of General Psychiatry, 41, 643-649.

Nurcombe, B. (in press). The evolution and validity of the diagnosis of major depression in childhood and adolescence. In D. Cicchetti \& S. L. Toth (Eds.), Developmental approaches to depression. Rochester Symposium on Developmental Psycho. pathology (Vol. 4). Rochester, NY: University of Rochester Press.

Puig-Antich, J. (1986). Psychobiological markers: Effects of age and puberty. In M. Rutter, C. E. Izard, \& P. B. Read (Eds.), Depression in young people: Clinical and developmental perspectives (pp. 341-382). New York: Guilford.

Radke-Yarrow, M., \& Zahn-Waxler, C. (1990). Research on children of affectively ill parents: Some considerations for theory and research on normal development. Development and Psychopathology, 2, 349-366.

Rose, D., \& Abramson, L. Y. (in press). Developmental predictors of depressive cognitive style: Research and theory. In D. Cicchetti \& S. L. Toth (Eds.), Developmental approaches to depression: Rochester Symposium on Developmental Psychopathology (Vol. 4). Rochester, NY: University of Rochester Press.

Rutter, M. (1986). The developmental psychopathology of depression: Issues and perspectives. In $\mathrm{M}$. Rutter, C. E. Izard, \& P. B. Read (Eds.), Depression in young people: Clinical and developmental perspectives (pp. 3-32). New York: Guilford.

Rutter, M. (1988). Epidemiological approaches to developmental psychopathology. Archives of General Psychiatry, 45, 486-495. 
Rutter, M., \& Garmezy, N. (1983). Developmental psychopathology. In E. M. Hetherington (Ed.), Manual of child psychology, Vol. 4: Social and personality development (pp. 775-912). New York: Wiley.

Rutter, M., Izard, C. E., \& Read, P. B. (Eds.). (1986). Depression in young people: Developmental and clinical perspectives. New York: Guilford.

Sroufe, L. A., \& Rutter, M. (1984). The domain of developmental psychopathology. Child Development, 55, 17-29.
Trad, P. (1987). Infant and childhood depression: Developmental factors. New York: Wiley.

Tronick, E., \& Field, T. (Eds.). (1986). Maternal depression and infant disturbance. New directions for child development (No. 34). San Francisco: Jossey-Bass.

Zahn-Waxler, C., \& Kochanska, G. (1990). The origins of guilt. In R. Thompson (Ed.), Nebraska Symposium on Motivation, Vol. 36: Socioemotional development (pp. 183-258). Lincoln: University of Nebraska Press. 